Discussion Paper No. 98-37

\title{
Public Research and Industrial Innovations
} in Germany

Marian Beise and Harald Stahl 


\section{Non-Technical Summary}

The paper deals with the effects of publicly funded research at universities, polytechnics and federal and state financed research labs on industrial innovations in Germany. In order to understand the current state of public research institutions in Germany, chapter two shortly describes its historical context, characterized by the traditional Central European view of natural science as a value in itself, the inertia of public institutions and tensions between federal and state responsibility for science policy.

In the third chapter we will deal with the following question: Are innovating companies able to identify the contribution of public research to industrial innovations and trace the source of these innovations? In a postal questionnaire, 2,300 companies were asked whether they had introduced innovations between 1993 and 1995 that would not have been developed without public research. Less than one tenth of product or process innovating firms said that they had introduced public-research-based innovations. The public-research-based products account for approximately 5\% of all sales with new products. Even more important are the differences in the effectiveness of technology transfer between different types of public research institutions. Universities are cited by firms with publicly supported innovations as the most important source, although publicly financed labs get almost as much citations. When firms were asked to name the most important public institutes, they most frequently cited the institutes of the Fraunhofer-Society. It seems obvious that their technology transfer is spurred by the higher share of research funds from industry. Big science labs are almost invisible, suggesting that their technology transfer to industrial firms still lacks effectiveness.

One of the basic findings is that a considerable share of companies can indeed identify product and process innovations which they would not have developed in the absence of recent research of public institutions. The results are similar to the findings of Mansfield (1991) for the U.S. On the side of the firms, we find that German firms with R\&D activities are more likely to profit from public research. Private and public research thus complement each other. Proximity may not have the same importance in Germany than in other countries, especially the U.S. The thesis that proximity is important especially for high-tech or R\&D-intensive industries is clearly rejected in the case of Germany. Although firms tend to cite research institutions that are located in their local area, firms which are closer to the public research have no higher propensity to receive public research spillover. Contrary to the widely held opinion that proximity to public research institution does promote collaboration between firms and public research institutions and increases the amount of received knowledge spillovers. Firms with a high $R \& D$ intensity cite remote public research institutes more frequently than less R\&D intensive firms, suggesting that in Germany high-tech does not depend on co-location of public and private research. Yet, polytechnics tend to support small companies within their region, while universities and other research labs transfer knowledge more effectively to larger companies with no regional priority. Still, the most critical success factor for technology transfer is a firm's own R\&D activity. 


\section{Zusammenfassung}

Wie viele industrielle Innovationen bringt die öffentliche Forschung hervor? Die vorliegende Untersuchung versucht, diese Frage zu beantworten und damit die wirtschaftliche Rechtfertigung für Finanzierung und Durchführung von natur- und ingenieurwissenschaftlicher Forschung in öffentlichen Forschungseinrichtungen empirisch zu überprüfen. Hierfür wurden rund 2.300 Unternehmen in der vierten Innovationserhebung von ZEW und infas im Jahr 1996 gefragt, ob sich unter ihren zwischen 1993 und 1995 eingeführten Innovationen neue Produkte und Prozesse befanden, die ohne die neueren Forschungsergebnisse von Hochschulen und anderen öffentlichen finanzierten Forschungseinrichtungen nicht oder nur mit zeitlicher Verzögerung von mehr als einem Jahr aufgenommen worden wären. Knapp $9 \%$ der Unternehmen mit Innovationen in dem betrachteten Zeitraum bejahten diese Frage. Mit den Produkten, die nur mit Hilfe der öffentlichen Forschung zustande kamen, wurden 1995 allerdings weniger als $5 \%$ des gesamten Umsatzes mit neuen Produkten gemacht. Der Technologietransfer von den öffentlichen Forschungseinrichtungen wird dabei entscheidend von den eigenen FuE-Aktivitäten der Unternehmen begünstigt. Sie sind nötig um die wissenschaftlichen Ergebnisse im Unternehmen in marktgerechte Innovationen umzusetzen. Dagegen wirkt sich die räumliche Nähe zu Forschungseinrichtungen, die unter dem Stichwort regionale High-Tech-Agglomerationen diskutiert wird, nicht auf den Technologietransfer aus. 


\title{
Public Research and Industrial Innovations in Germany
}

\author{
Marian Beise $^{\mathrm{ab}}$ and Harald Stahl ${ }^{\mathrm{a}}$ \\ ${ }^{a}$ Centre for European Economic Research (ZEW), Mannheim, \\ ${ }^{\mathrm{b}}$ Institute for Applied Management Science and Corporate Strategy, University of \\ Karlsruhe
}

\begin{abstract}
This paper deals with the effects of publicly funded research at universities, polytechnics and federal research labs on industrial innovations in Germany. We discuss the characteristics of companies that benefit from the findings of public research institutions. In questioning 2,300 companies we found that less than one tenth of product or process innovating firms introduced innovations between 1993 and 1995 that would not have been developed without public research. These new products amount to approximately 5 percent of all new product sales. Regressions show that firms' own R\&D support the ability to absorb the findings of public research and turn them into innovations. Contrary to the widely held opinion that proximity to public research institutions does promote collaboration between firms and public research and increase the amount of received knowledge spillovers, we found no higher probability of publicly supported innovations for firms in Germany that are located near universities or polytechnics.
\end{abstract}

JEL classification: $\mathrm{O} 32, \mathrm{O} 38$

Keywords: technology transfer, industrial innovation, knowledge spillovers

\section{Acknowledgement}

The authors thank Stefan Schalk, Thomas Forst, Thorsten Doherr and Thomas Eckert for support in the preparation of the database. We are grateful to Georg Licht and two anonymous referees for their helpful comments. 


\section{Introduction}

Since Arrow's (1962) famous address at an NBER-conference in 1960, it is commonly believed that the incentives for private investment in R\&D are below the social optimum because of the public good character of knowledge or what we now call knowledge spillover effects. Beside the low appropriability of R\&D-expenditure in basic research, it is assumed that small firms which operate in niche markets cannot afford large R\&D-labs. Even large firms, mostly risk-averse and short-term oriented, would not bear the large investments necessary because of indivisibility and high uncertainty. In addition, firms are constrained to financing their R\&D-projects by information asymmetries in financial markets (Harhoff, 1998). In sum, failure in financial and technology markets, indivisibility and economies of scale in R\&D add up to a private under-investment in R\&D. ${ }^{1}$ It is suggested that the government should finance research at public research institutions in order to attain the socially optimal R\&D investment. ${ }^{2}$ The findings of publicly funded research are expected to be subsequently used by private businesses for industrial innovations. It follows that benefits of publicly funded research must be qualified against its cost. As this is the main justification for public funds for research at public research labs, economists and politicians are interested in assessing the real economic impact of publicly funded research.

The economics of public knowledge production can be divided into three basic means: Education (human capital), research, and consultancy. Support for innovations of private firms is only one of its missions, but it is achievable by all three means, since knowledge transfer from research institutions to private firms flows through many channels. New knowledge generated by public research is transferred to the industry by publication of research papers, $R \& D$ contracts or $R \& D$-cooperation with private companies. Informal personal contacts and the hiring of researchers from public institutions are more frequently used. Mainly US-universities are also known for their summer seminars for scientists and engineers of R\&D firm labs or for business executives. It is usually suggested that public research falls short of the full impact it could or should have. In Germany, like in other countries, inefficiencies in the transfer of technology and lack of orientation towards the commercialisation of scientific results are predominantly made responsible for ineffective public research and not the quality of research in terms of scientific performance. ${ }^{3}$ It could be argued that on the one hand government funds research, while on the other it fails to set an incentive for scientists to support commercialisation, when solely evaluated by their scientific performance. Instead, technology transfer requires active participation of the inventor in the com-

1 Estimations for the US of the annual social rate of return to R\&D by the empirical literature vary between 20 and 100 percent (Nadiri, 1993). After reviewing the empirical literature Jones and Williams (1997) conclude that the R\&D spent by private firms might only be a quarter of what is socially optimal.

2 For a discussion of the basic economic idea for public research see Leyden and Link (1991b).

3 For an assessment of scientific performance and marketability of publicly funded research institutes in Germany see BMBF (1998). 
mercialisation phase of innovations. Jensen and Thursby (1998) delineate how technology transfer from public research institutions is ineffective if faculty members have no incentives to devote effort to the innovation after the invention has been licensed to a firm.

For economists public basic research is supposed to enlarge the knowledge base and thus enhance opportunities of private firms to innovate rather than to generate innovations apart from private business (Nelson, 1986, Dasgupta, David, 1994). Particularly in science-based technologies like biotechnology, academic science might yield the highest economic reward. Yet, scholars of industrial innovation history mainly disagree with the traditional idea that science leads to technological applications. They argue instead that science is only occasionally used in the innovation process and that it interacts with technological progress (Kline, Rosenberg, 1986). In the interaction of science and technology, Brooks (1994) suggests that technology is at least of equal importance for science as science is for technology. Stephan (1996) adds more evidence to the endogenous character of academic research. First, scientists get their inspiration from collaboration with firms and select highly profitable technological fields where relative salaries are high and second, successful firms support academic research and that government support for science reflects the well-being of the economy. Even more radically Kealey (1998) pleads for the irrelevance of public science to technological progress, today as well as in the past. Only applied research tied closely to product or process development can benefit industrial innovations. On the other hand, empirical observation show that technology can increasingly be related to science. For instance, Narin et al. (1997) show that patents increasingly refer to papers of scientific journals. What seems to be true, however, is that technology transfer between public research institutions and private business is most successful if it is embedded in targeted and well managed collaborative research projects (e.g. Bloedon, Stokes, 1994). This is reflected by the management literature on technology transfer focussing on the relationship management to public research (e.g. Gemuenden, Walter, 1997). The pipelinemodel of new knowledge from publicly funded science spilling over to companies as a public good could be considered as ineffective and obsolete.

The question we will address in the third chapter is: Can the contribution of public research to industrial innovations be identified and traced back to their source by innovating companies? Although there are attempts to assess the economic benefits of technology transfer from public research and how technology transfer should be managed in companies and in public research institutions to make the best commercial use out of public research, little is known about the quantitative impact of public research on industrial innovations. ${ }^{4}$ Some progress has been made in determining factors that affect technology transfer from public research institutions to companies, but a quantitative measurement of how many innovations have been enabled by public research

4 Attempts for an assessment of the benefits of pure science were already made in the projects Traces and Hindsight and by Gibons and Johnston (1974), see Martin and Salter (1996) for a review of these studies, which show that innovations which are based on pure science exist. However, these studies lack representative quantities. 
seems to be an odd task. So far only Mansfield (1991) has tackled this question by asking a sample of major companies about product and process innovations, which would have not been developed in the absence of public research. Other studies detect the impact of public research indirectly by estimating the correlation between public research and innovation activity over regional. In this approach a regional coincidence of public research and innovations measured as the number of innovations or patents is interpreted as regional spillovers from public research (Jaffe 1989, Acs, Audretsch, Feldman, 1992).

The study starts following the approach of Mansfield (1991) and, in a second step, examines the assumption of the regional spillover-pool approach that regional closeness between firms and knowledge source stimulates technology transfer. The prime aim of our study is to assess the economic justification for publicly funded research that directly supports industrial innovations which otherwise would not be developed by private businesses. ${ }^{5}$ Secondly, we want to identify the type of public research as well as firms most likely to accomplish the public objective. Finally, we will pursue the question of whether closeness of firms and research institutions has a positive effect on commercialisation of findings of public research.

The current state of the public research infrastructure in Germany cannot be understood without looking at how public research is embedded in the German sociopolitical system. After discussing the historical evolution of the rational for the institutions of publicly funded research in Germany we present results of a survey of about 2,300 companies in the manufacturing sector. Firms were asked the question of Mansfield (1991) whether they had recently introduced innovations, which would not have been developed in the absence of public research. In addition, we asked firms with public research based innovations to cite the most important public knowledge source. In the fourth chapter we discuss the features of firms with these public science-based innovations. In locating firms and cited research institutions we can include the effect of the distance between these two organisations on the propensity to adopt knowledge spillovers from public research.

\section{Publicly Funded Research in Germany}

\subsection{The Institutional Structure in Germany}

Germany posseses a diverse range of public research institutions which are committed to different means and technology transfer channels. The publicly funded R\&Dinfrastructure in Germany can been subdivided into three groups: Universities, polytechnics, and non-university research. Looking at the public research infrastructure, at first glance it seems that Arrow's hypothesis of under-investment in private $R \& D$ and spillover effects has received the most ardent support in Germany. In the 1990s federal

5 Of course, there are other reasons for publicly funded research especially for basic research like cultural richness, education, national defence and support for underdeveloped nations, etc., which we will not address in this paper. 
and state governments in Germany have spent about 25 billion DM per year for R\&D, half of which goes to universities and polytechnics and half to public research labs. In addition, DM 5 billion is directly given to private businesses as project-related subsidies for R\&D. We estimate the number of (full- and part-time) researchers within natural sciences, engineering and medical faculties of publicly funded institutions at 122 thousand in 1993. Of course, scientists at universities and polytechnics (Fachhochschulen), which make up 70 percent of this figure, are occupied with teaching and some of them spend only a little time on research. The R\&D-share of their work varies between 30 percent (clinics) and 60 percent (engineering) for universities and drops to 5 percent for polytechnics (Hetmeier, 1998). The full-time equivalent of public scientists is only 50 percent of the head-count. However, statistics collected by the OECD (1997) show that Germany spends more on R\&D in the higher education and government related sectors as a percentage of GDP than most of the other OECD countries including the US, if the defence related budget is excluded.

Germany's public research infrastructure was not built up from the scratch to fulfil the economic goal set by the hypothesis of private under-investment in R\&D. ${ }^{6}$ It evolved in a complex environment characterised by the traditional Central European view of natural science as a value in itself and by the demand from industry, by the inertia of public institutions and tensions between federal and state responsibility for education and research. Universities have a long tradition of research in natural and medical science reaching back to the middle ages. Universities of social and natural science are known mostly for teaching and basic research without aiming at any commercialisation. Their main transfer channel seems to be the publication of research results. Their share of research grants from industry remain low, between 1-15 percent of projectrelated research funds from external sources, meaning that only up to 3 percent of all research expenditures are financed by industry (Wissenschaftsrat, 1993). In contrast, technical universities have a long tradition of industry-related research. Similar to the US (Rosenberg, Nelson, 1994), technical universities have been formed since the last century to enforce inventions and technical applications of scientific findings but have subsequently focussed on basic research (Keck, 1993). They receive up to 40 percent of external research funds from industry, though it is less than 10 percent of all their research spending. As the public law impose some restrictions on technology transfer, universities have established legally independent external institutes in order to gain administrative flexibility (Abramson et al., 1997, p. 288). In 1993 these institutes made up about 4 percent of all research at universities, and this share has been increasing rapidly in the 1990s.

Polytechnics (Fachhochschulen) have a special role in Germany. Often, they are specialised in the same technical fields as local businesses and are supposed to support small and medium sized firms through consultancy and the supply of graduates. Polytechnics focus mainly on education, but also conduct research albeit on a much smaller scale than universities. The first polytechnics emerged from engineering schools and

6 For a more detailed description of academic and non-academic public research institutions in Germany, see BMBF (1996), Keck (1993), Abramson et al. (1997) and Schimank (1990). 
were complemented later by a number of newly established ones. They are now widespread within Germany and have gained a reputation for down-to-earth research and applicable engineering know-how, compensating the shortcomings of universities which are oriented towards basic research.

\subsection{The Development of Non-Academic Public Research}

While tradition-bounded universities offered limited potential for ambitious research policy, additional research labs were established by the federal or local governments to fill gaps in the wide spectrum of technology transfer to private business. The history of publicly funded research centres in Germany that have been established in addition to universities goes back to the last century. It is typical of these institutes that, when founded, their main mission was to support the national economy. Subject to a few exceptions, the justification for their establishment was to either maintain the international competitiveness of private companies or to close a German technological gap to other nations, mainly to the US. In 1887, the first public research agency, the Physikalisch-Technische Reichsanstalt, was founded under the initiation of Werner von Siemens, one of the first German industrialists (Cahan, 1989). In 1911 the KaiserWilhelm-Society was established with strong financial and ideological support of the German chemical and heavy industries. Some of its institutes were almost industrial research labs (Ritter, 1992, Johnson, 1990). After World War II, the institutes were reunited in the Max-Planck-Society (MPG) and became quite independent from industry, from were they now receive less than 1 percent of their total budget as research grants. Over time the MPG with its 60 institutes employing about 3,000 scientists in natural and medical sciences shifted away from industry-related research to basic research (Mayntz, 1991, p.53) and became concentrated on biology, physics and astronomy, but they are still strong in chemistry, material and medical science as well.

Together with the institutes of the Fraunhofer-Society the Max-Planck-Institutes are designed to complement research at universities and are often located within their proximity, even being headed by university professors. The Fraunhofer-Society (FhG), founded in 1949 in Bavaria as a geological institute, was soon transformed into an organisation of institutes for industry-like applied research. After a difficult start with the research community, which saw its public and private funds waning and therefore opposed the FhG, the latter was only able to survive in the late 1950s when the Defence Ministry fostered the institutes as their main research contractor. With the defence related source of funds at hand, the Fraunhofer-Society was deliberately joined by other already established public and private research institutes. In 1968, it was fully integrated in the research funding programme of the Federal Research Ministry and the share of defence related research decreased to less than 40 percent in the mid-1970s. Over time, the Fraunhofer-Institutes established themselves as the leading contract research institutions for industrial innovations in Germany. Its 47 institutes are comparatively small and regionally dispersed. Altogether they employ only 3,300 scientists and engineers. Whereas the MPG and big science labs receive full public funding, most of the Fraunhofer-Institutes receive a small share of their budgets as non-project-related public funds (about 40 percent). That is why they are keen to acquire research funds 
from industry and through public research programmes, each funding an additional 30 percent of the total budget.

In the 1990s, MPG and FhG together receive public funds of about three quarters of what the federal science centres receive, which is about 16 percent of the gross amount of Germany's public R\&D spending. The history of the federal big science labs started in the early 1950s with the promising prospects of nuclear energy, which was seen as the key to technological competitiveness. The nuclear euphoria was politically emphasised by the new Ministry of Nuclear Science, which orchestrated the public funding of nuclear research in big science labs. Their mission was to build nuclear research reactors, developed and operated in close collaboration with German industry, which also supplied financial resources. Competition between the states and their responsibility for research policy led to the establishment of five large research centres. These labs were finally financed by federal funds after the industry gradually lowered its financial commitment while developing its own indigenous technology or taking licenses of foreign reactor designs. For a while, the strategy of the German nuclear science programme seemed unsettled and was refocused several times, lastly on high temperature and fast breeder reactors which were finally abandoned in the 1990s. Though the federal research programme at first glance led to an internationally competitive German nuclear industry, after reviewing the German public reactor programme Keck (1980) recaps that its commercial benefit was marginal. Actually, there was little contribution by government research centres to the only commercially successful reactor type, the light-water reactor. Parallel to the phasing out of nuclear research programmes and even before the downturn of public support for nuclear energy in the late 1970s, the nuclear research centres diversified their activities from nuclear energy to nuclear waste management and unrelated new technologies like microelectronics, computer technologies and environmental science. For instance, the Geestacht research centre shifted to marine research after abandoning its first mission as a nuclear powered ship. Despite the vanishing importance of nuclear science, all these big-science labs still operate at full steam.

Besides these well known organisations there is a bunch of larger and smaller publicly financed research institutes and federal agencies with research activities like material testing, pharmaceutical approval or defence technology assessment. Though the main purpose does not always consist of technology transfer, they could still have some effect on industrial innovation. The so-called 'blue list' institutes are financed equally through funds of the federal and host state governments; research grants from industry are scarce. They employ about 5,000 scientists and engineers in the natural, engineering and medical sciences. The first public research institution mentioned, the Physikalisch-Technische Reichsanstalt, is now one of several federal agencies with R\&D activities in Germany, employing about 7,500 scientists and engineers in total R\&D. In addition, some institutes which are supposed to be supporting local industry are funded exclusively by the federal states. 


\subsection{Policy Shifts}

In the mid-1960s science policy moved towards federal responsibilities. The Ministry for Nuclear Science was renamed into the Research Ministry, and new public research centres were established. Federal government intended to influence the direction of state dominated research policy in Germany through big science labs which were financed almost entirely by federal funds and the Fraunhofer-Institutes. Primary concerns stated in official statements in favour of public research centres focussed on the technological gap between Germany and the US in certain technological fields (Keck, 1976, p. 137, Schimank, 1990). Research planning became the key word of science policy (Tritschler, 1990). The dominance of the US-aircraft industry fostered by defence-related subsidies led to the convergence of the aerospace industry in Europe and publicly funded research at the national laboratory of space and aviation (DLR). It is now the largest of the big science centres in Germany. The other most obvious technological gap to be closed was that of the computer industry. For this task, the "Gesellschaft fuer Mathematik und Datenverarbeitung" (GMD) was founded in 1968, though specialised in computational mathematics. Public departments were designated as the first users of demonstration projects developed by the GMD (Wiegand, 1990). Later, other government research centres were established which focused more on nonindustrial research like the AWI for polar research or the DESY in Hamburg, a large electron collider ring.

After the short period of the Brandt-administration, which shifted policy priorities towards the prevention of side effects of new technologies and to increasing the quality of life, the objective of public research was again refocused on economic motivations under chancellor Schmidt in the mid-1970s marked by calls for more technology transfer from public research to industry through close collaboration with the industry (Ritter, 1992). Technology policy was thus seen as an active industrial policy (Hauff, Scharf, 1975). In the 1980s, it became officially recognised that expectations of intensive technology transfer from federal funded research centres would not be met. The mission of big science centres then shifted from development of large technical systems to the study of aspects of large technical systems (Federal Government cited by Ritter, 1992, p. 107). With the liquidation of the reactor programmes (high-temperature and fast breeder reactors) the labs finally lost their large scale industrial innovation targets, which, in economic terms, were substituted by ill-defined socio-economic complexes like environment, energy and health. Besides basic research, they should generally promote further developments of technologies in these fields including aerospace (BMBF, 1996). They also lost their clear distinction from basic science at universities. Since then, their capabilities of generating industrial innovation have been regarded as limited, achieving at most spin-off innovations. Again, their public funds have not been dwindling. One reason for their everlasting survival is that universities and polytechnics are placed within the responsibility of state governments. The MaxPlanck-Society with some of their directors being Noble prize winners vehemently insists on its independence, leaving government research centres as the main vehicle for federal science and technology policy. 


\subsection{The Divorce Between Basic and Applied Research}

From this overview of the German public research infrastructure, we made clear that the establishment of public research was mainly justified with economic benefits. After world war II the distinction between basic and applied science emerged not only in the US (Brooks, 1996) but in most other industrialised countries as a paradigm of public research (Stokes, 1997). Basic research, which is in Vannevar Bush's words performed without premature thought of practical use, became seen almost as the equivalent of the private under-investment in R\&D. In Germany the separation of pure and applied science was traditionally institutionalised in universities of technical and natural sciences. But it was not until the integration of the Fraunhofer-Society as the third pillar of the German public research system, that the division between basic and applied research was officially carried out in the non-academic public research sector as well (Hohn, 1989). In 1973, the then renamed Federal Ministry of Research and Technology finally laid down the division of labour between MPG, which subsequently totally abandoned applied research and concentrated on basic research, big science labs, aimed at industry-oriented basic research, and the FhG-Institutes, responsible for applied research through contract-research. In effect, only the institutes of the Fraunhofer-Society have a clear mission for industrial innovations, all other publicly funded institutions are directed towards basic research with the prospect of spin-off innovations. For example, the MPG as Abramson et al. (1997, p. 312) concludes, always emphasizes technology transfer, but it never views the success of transfer as a criterion of evaluation.

Herein lays the main public criticism of the current state of public research (Stokes, 1997). It is what Shapley and Roy (1985) call the „myth of the divorce between basic research and applications": that basic research has to be separated from applied research to yield valuable results. Although justified mainly by economic reasoning, large parts of public research seems to retreat to vague long term effects of basic knowledge not amenable to testing. If there is no inherent separation of basic and applied research or if science does not lead automatically to technical applications, it is not enough for public research to concentrate on pure basic research to fulfil its economic objective. By participating in publicly funded projects with industry in the 1990s, even big science in Germany is moving back towards active development of industrial applications. Yet, despite the gradual transition of public research institutes, they remain in the crossfire of industrial critics due to the lack of efficiency of technology transfer. We now turn to the view of the firms and try to assess the economic benefits of the different institutions of public research by examining industrial innovations, which have been enabled by public research.

\section{Public Research Underlying Industrial Innovations}

Most of the empirical studies of public research on industrial activities try to verify effects indirectly without identifying what channels were used mostly. The analysis does not identify the channels of technology transfer either, but it defines exactly the effects of public research on industrial innovation. As already mentioned, the motiva- 
tion for public research is that private firms would not invest in research because they could not fully appropriate the profit of the findings albeit the research would lead to useful industrial innovations. To identify the kind of research in place for omitted private activities and to distinguish it from pure outsourcing of private $R \& D$ tasks to public research institutions, we have to stipulate that the company would not have done the $R \& D$ on their own if it had not been funded and performed by the government.

In the fourth year of the annual innovation survey ${ }^{7}$ conducted by the ZEW in 1996 the companies were asked almost the same question Mansfield (1991) used in his study. In our survey firms were asked whether they have introduced an innovation between 1993 and 1995 that could not have been developed without the support of research institutions. In the postal questionnaire the question was placed directly after the companies had to estimate the share of sales with new or significantly improved products and the cost reduction of new processes introduced since 1993. The companies were to judge, ,whether any of these innovations could not have been developed or only with a delay of at least one year in the absence of recent research at universities and other public research institutions, and what share of sales these innovations covered in 1995. The qualifications were implemented to exclude the outsourcing of R\&D projects which could have been done in-house as well but at higher costs. ${ }^{8}$ The share of companies which introduced innovations which could not have been developed in the absence of public research says not much about the importance of these innovations. To quantify the impact of public research on industrial innovation the firms that had introduced new products between 1993-1996 were subsequently asked to estimate the share of sales of these new products. To trace back the academic support of industrial innovation we finally asked the companies to name not only the group of academic source but also single institutions. The distribution over specific research institutions will be discussed in the third subsection of this chapter.

\subsection{Firms with Public Research-Based Innovations}

Slightly less than 9 percent of all firms which introduced product or process innovations between 1993 and 1996 received the support of public research for their innova-

7 The Mannheim Innovation Panel is part of the community innovation survey (CIS), a joint effort of Eurostat and EU Commission to collect firm-level data on input and output on innovation. All tables of the descriptive part show expanded figures. See the data appendix for the data description.

8 Of course, a postal question is prone for misunderstandings. Unlike Mansfield (1991) we did not specify just how far back in time the word 'recent' actually means. The only purpose of 'recent' is to prevent views of the like that everything is originally based on progress in academic science like microelectronic is based on the quantum theory or radio telecommunication on Maxwell's laws. Mansfield (1991) himself notes that data was obtained after considerable discussions with respondents. Yet, we are convinced through a dozen personal interviews we made with the heads of R\&D departments, who were predominantly asked in the survey, that the question is quite comprehensible and that the answers are not heavily biased towards over- or under estimation of public research. See data appendix for a further discussion. 
tions (table 1). Looking only at the R\&D-intensive industries ${ }^{9}$ the figure rises to 16 percent. Taking into account that the base group comprises all firms with 5 or more employees and which has used at least one new machine during that time ${ }^{10}$, the share of firms with public-science-based innovations is rather high and exceeds the share of companies which rate public research as very important for their innovations.

Table 1

Share of companies with innovations which could not have been developed without recent public research (\%) between 1993-1996

\begin{tabular}{|c|c|c|c|c|c|c|}
\hline \multirow[t]{2}{*}{ Industry } & \multicolumn{4}{|c|}{$\begin{array}{l}\text { Firms with pub- } \\
\text { lic-research-based of which: } \\
\text { innovations }\end{array}$} & \multirow{2}{*}{$\begin{array}{l}\text { Firms with } \\
\text { public-research } \\
\text { based product } \\
\text { innovations to } \\
\text { all product- } \\
\text { innovators }\end{array}$} & \multirow{2}{*}{$\begin{array}{l}\text { Firms with } \\
\text { publ.-research- } \\
\text { based process } \\
\text { innovations to } \\
\text { all process- } \\
\text { innovators }\end{array}$} \\
\hline & $\begin{array}{l}\text { to all product } \\
\text { or process- } \\
\text { innovators }\end{array}$ & $\begin{array}{l}\text { Products } \\
\text { only }\end{array}$ & $\begin{array}{l}\text { Processes } \\
\text { only }\end{array}$ & $\begin{array}{l}\text { Products } \\
\text { and proc- } \\
\text { esses }\end{array}$ & & \\
\hline Manufacturing & 8.5 & 5.5 & 1.5 & 1.5 & 7.9 & 3.4 \\
\hline$R \& D$ intensive & 15.9 & 12.0 & 2.4 & 1.5 & 14.0 & 5.2 \\
\hline non-R\&D-intens & 6.2 & 3.5 & 1.3 & 1.4 & 5.7 & 2.9 \\
\hline
\end{tabular}

Source: ZEW Mannheim Innovation Panel

Public research had a much higher impact on new products than on new processes. This is no surprise, since a lower share of private $R \& D$-expenditure is pointed at process innovation. In non-R\&D-intensive industries, 42 percent of the firms introducing innovations with the help of public research developed new processes. In the R\&Dintensive industries the share was only 29 percent. This could simply reflect higher incentives in the non-R\&D-intensive sector for price-cutting process innovations relative to new products than in R\&D-intensive industries. The overall share of firms with publicly backed process innovations, though, is still a bit lower in non-R\&D-intensive industries.

The second part of the question asked for the sources of public research which were most important for the development of innovations (table 2).

9 In our study we use the classification of BMBF (1998). R\&D intensive industries spend more than 3 percent of sales for R\&D. This group is further subdivided into advanced technologies and cutting edge technology with the latter subgroup spending more than 8 percent of sales for R\&D. R\&D intensive industries include chemicals, machinery, electrical machinery, computers, medical, precision and optical instruments, motor vehicles and the aerospace industry. Within these industries pharmaceuticals, agri-chemicals, telecommunication equipment, electronic components and aircraft are cutting edge technologies.

10 The OECD-definition of innovation was used in the survey. It includes products and processes new to the firm (OECD, 1996). Thus, even some imitations and the adaptation of new machinery are innovations. 
Table 2

Distribution of sources without which innovations from 1993-1996 could not have been developed $(\%)$

\begin{tabular}{|c|c|c|c|c|}
\hline \multirow[t]{2}{*}{ Source $^{a}$} & \multirow{2}{*}{$\begin{array}{l}\text { Firms with public- } \\
\text { research-based } \\
\text { innovations }\end{array}$} & \multicolumn{3}{|l|}{ of which: } \\
\hline & & products only & processes only & $\begin{array}{l}\text { products and } \\
\text { processes }\end{array}$ \\
\hline all & 100.0 & 100.0 & 100.0 & 100.0 \\
\hline Universities & 40.7 & 45.8 & 24.7 & 38.2 \\
\hline Polytechnics & 17.1 & 14.8 & 17.5 & 25.7 \\
\hline Other public labs & 40.0 & 45.4 & 45.5 & 12.7 \\
\hline no assignment & 20.3 & 13.3 & 28.6 & 38.2 \\
\hline
\end{tabular}

${ }^{\mathrm{a}}$ Multiple answers possible

Source: ZEW Mannheim Innovation Panel

Out of the three groups of public research institutions and universities were cited equally often. Less than one fifth mentioned the polytechnics. Compared to their low research budget this turns out to be a surprisingly high figure. A substantial share of the firms did not specify the particular source of support, either because the respondent did not know where the research support originally came from or because he did not want to name the source, for it represents crucial information for the firm.

Looking at the size distribution of firms (table 3), we find that larger companies give priority to universities, which are normally much better equipped than polytechnics, whereas smaller firms receive relatively more support from polytechnics and, somehow surprisingly, from publicly financed research labs. It is possible that universities discriminate against small firms in favour of large firms because larger firms are more attractive in terms of funding and proximity to basic research. It does not support the common view that small firms rely mostly on polytechnics. Compared to polytechnics, universities still play a role in innovation for small companies.

Table 3

Size distribution of firms with innovations introduced between 1993-1996 which could not have been developed in the absence of public research $(\%)$

\begin{tabular}{lrrrr}
\hline Source $^{\mathrm{a}}$ & \multicolumn{1}{l}{ Total } & \multicolumn{3}{c}{ of which by number of employees } \\
\cline { 3 - 5 } & & $5-50$ & $50-500$ & 500 and more \\
\hline all & 100.0 & 100.0 & 100.0 & 100.0 \\
Universities & 40.7 & 31.7 & 50.8 & 48.2 \\
Polytechnics & 17.1 & 24.5 & 8.3 & 16.5 \\
Other public labs & 40.0 & 43.4 & 35.7 & 41.2 \\
no assignment & 20.3 & 12.8 & 28.4 & 31.2 \\
\hline
\end{tabular}

${ }^{\mathrm{a}}$ Multiple answers possible

Source: ZEW Mannheim Innovation Panel 


\subsection{Sales of Public-Research-Based-Innovations}

The share of sales with new products introduced to the market in the 3 year period between 1993 and 1996 is about one third with few differences between small and large firms (table 4). The share of the public-research-based products of all firms that introduced products with the help of public research is one quarter of all sales with new products. Once able to transform findings of public research into innovations, smaller firms tend to cover a higher share of sales with publicly supported innovations than larger companies. We have two explanations for this. First, smaller firms have fewer products in their portfolio and given the length of the product-life-cycle does not vary between small and large firms, they develop fewer innovations in a 3-year period. Therefore, every single new product has a higher share of sales to total sales with new products. Taking only small firms with public-research-based innovations leads to higher shares of sales of these innovations. Secondly, smaller firms do more often compensate a lack of basic knowledge and research abilities with partners of the public research infrastructure than companies with large R\&D labs, which more often outsource auxiliary $\mathrm{R} \& \mathrm{D}$ functions or non-crucial developments, they tend to keep inhouse to prevent knowledge drains to other firms. Thus public-research-based innovations of smaller firms have a higher quality and a higher impact on their sales than their pure in-house innovations.

Table 4

Average share ${ }^{a}$ of sales of new products, which could not have been developed in the absence of public research (\%)

\begin{tabular}{lcc}
\hline $\begin{array}{l}\text { Number of em- } \\
\text { ployees }\end{array}$ & $\begin{array}{l}\text { new products } \\
\text { to total sales }\end{array}$ & $\begin{array}{l}\text { public-research-based } \\
\text { products to total sales } \\
\text { of new products }\end{array}$ \\
\hline $5-49$ & 31 & 46 \\
$50-499$ & 31 & 36 \\
500 and more & 34 & 22 \\
Total & 34 & 25 \\
\hline
\end{tabular}

${ }^{\mathrm{a}}$ weighted by total sales

Source: ZEW Mannheim Innovation Panel

The sales of public-research-based product innovations of a 3-year period can be estimated at roughly DM 20 billion (table 5). That is less than 5 percent of total revenue for new products of the manufacturing sector in Germany. Since multiple answers for the source were possible, the sales cannot be divided between the three groups of sources. Yet, most of these sales with research-based products can be attributed to universities, that is 78 percent of the sales with public-research-based products are from firms, which name universities as a main source of knowledge, compared to 63 percent for research labs and 38 percent for polytechnics. Surprisingly, slightly more sales with public-research based products are made by firms of non-R\&D-intensive industries. The share in all new products is almost the same in $R \& D$ intensive and in non-R\&D intensive sectors. Research of polytechnics is used much more for non-R\&D-intensive 
products, suggesting that high-tech sectors prefer research from universities and research labs for their main product innovations.

Considering the amount of public funds of DM 25 billion or 30 percent of the gross national R\&D expenditure per year public research institutions receive, one may also postulate that the attempt to compensate the assumed under-investment of private $R \& D$ by public spending on research institutions generated an oversized public research infrastructure in Germany. This public research does not seem to yield social welfare in form of spillovers to industrial innovations as much as it costs. This conclusion can clearly be countered with the fact that we did not measure all effects of public research on industrial innovations. This truly underestimates the benefit of public research on industrial innovation on the whole. First, we did not include the savings achieved with processes that could not have been developed without public research. It can also be argued that the survey identified only a fraction of products where public research is vital but not consciously recognised by the firm. While product imitations are included in the total industry sales of new products, it is likely that most of the imitations of new public-research-based products were not included by the imitating companies (as it should be), simply because the imitator was not aware of the role public research played in the development. Besides that, it is almost impossible to measure all additional effects of intermediate products like semiconductors which enable new functions of other products.

Table 5

Estimated sales with new products introduced between 1993-1996, which would not have been developed without public research

\begin{tabular}{|c|c|c|c|c|c|}
\hline \multirow[t]{2}{*}{ Industry } & \multirow{2}{*}{$\begin{array}{l}\text { Sales of new } \\
\text { public-research- } \\
\text { based products } \\
\text { Billions of DM }\end{array}$} & \multirow{2}{*}{$\begin{array}{l}\text { as percentage } \\
\text { of total industry } \\
\text { sales of new } \\
\text { products }\end{array}$} & \multicolumn{3}{|c|}{ Distribution of source ${ }^{\mathrm{a}}$ (in percent) } \\
\hline & & & Universities & Polytechnics & $\begin{array}{l}\text { Other } \\
\text { public labs }\end{array}$ \\
\hline Manufacturing & 19.4 & 4.5 & 78 & 38 & 63 \\
\hline R\&D-intensive & 9.4 & 4.7 & 69 & 10 & 68 \\
\hline non-R\&D-intensive & 10.0 & 4.3 & 87 & 64 & 59 \\
\hline
\end{tabular}

${ }^{a}$ Multiple answers possible

Source: ZEW Mannheim Innovation Panel

Secondly, the assumption of under-investment of private R\&D does not need the condition of firms lacking the ability to develop a new product or process mainly because of low appropriability of knowledge or financial restrictions. Although we tried to formulate the question as neutral as possible, it can be difficult for firms to admit in retrospect that they would not have introduced the innovation if solely relying on their own resources. Thirdly, public research in Germany can be useful for companies outside of Germany, i.e. Japanese firms have a reputation for using findings of basic research in Germany and turning it into successful innovations. Fourthly, we include only short-term effects of public research, but basic research is said to be used for in- 
dustrial innovations a fairly long time after publication. Adams (1990) finds time lags of 10-30 years between the appearance of public research results in scientific articles and their effect on productivity. Many firms do co-operate with public research institutions on strategic long term research projects only with no explicit agenda of product or process development in order to keep the core-knowledge of their innovations inhouse. These projects could also be of benefit to industries, but final effects to firm specific new products or processes are hard to assign.

On national level, the argument for basic research is that nations can get a head start in new technologies where markets are not developed yet and technological progress is pushed mainly by advances in science. Nations could subsequently turn that basic knowledge into a long-term national comparative advantage after first applications of the new technology emerge and markets develop. Biotechnology or microelectronics are given as examples for national advantages through science. These long-term effects are not only hard to measure, but also disputable. First, it is not clear whether leadapplications always occur where science is most advanced. It could also occur where users benefit most from the new technology. It would be more effective to transfer scientific knowledge between advanced nations than to run user-producer-interaction, which is often essential for the commercialisation of new technologies (Lundvall, 1988) over a long distance. The second argument against this point is that progress in science is often pushed by technological inventions. In line with the aim of the study we excluded innovations which were developed with knowledge from public research production but which were developed by private business otherwise, even if public research would have been conducted.

As it has been said before, there are other technology transfer channels to support industrial innovations which are not likely to be included in our new product measurement, like scientists working in private R\&D labs using their knowledge stock they built up in public labs. It was also often observed that public R\&D does stimulate private $R \& D$ (Leyden, Link, 1991a). The innovations derived from the additional private $R \& D$ should also be taken into account as effects of public research. Keeping this in mind, these estimates are a step to evaluate the short-term direct effect of public research on industrial product innovation.

\subsection{Distribution of Public Research Sources}

A further question is where exactly the contribution to industrial innovation came from. Support may be distributed evenly among universities and other publicly financed research institutes, reflecting only the distribution of research staff, or concentrating on particular institutions which turn out to be more effective. Mansfield and Lee (1996) seem to support the common view of the American academic research infrastructure that mostly privately financed elite universities such as MIT, Harvard and Stanford, which are world leaders in science and technology, attract the highest research grants from businesses, thus becoming most decisive in industrial innovations whereas the majority of academic institutions display a rather mediocre performance when it comes to valuable research results which may be used for high-tech industrial innovation. 
To trace back the academic support of industrial innovation we asked the companies to further name public research lab, university or polytechnic that was most important for their innovations. About 129 companies out of 169 that tagged at least one kind of source could or were not reluctant to give the name of the most supportive institutions. These respondents cited 196 public research institutions altogether, of which 120 were different ones, which means that on average every company named a different source. At first glance the variety of citations suggests that there are plenty of different sources in Germany that generate valuable information for industrial innovation and that academic support is not excessively concentrated. A closer look shows that the distribution is actually almost the same as in the Mansfield study. The top four research institutions received almost 30 percent and the top ten got 43 percent of the citations but employ only 23 percent of the scientific staff. Thus, academic support in Germany seems to be just as much concentrated on single institutions as in the US.

As expected, the institutes of the Fraunhofer-Society were cited most frequently. ${ }^{11}$ With few exceptions these institutes were cited generally, so that the particular institute could not be identified. Since the Fraunhofer-Society as a whole is as large as a university or one of the large federal science centres, we treat its institutes as one institution. It corroborates the first presumption that the institutes of the Fraunhofer-Society play the dominant role within the group of institutions other than universities and polytechnics, which in the previous chapter proved to be effective regarding industrial innovations. Not surprisingly, large technical universities with engineering faculties were cited most, leaving traditional universities which focused on natural science far beyond. The most cited university was Aachen, which is also the only German university cited in the Mansfield-study by US companies. This clearly confirms the superior role of Aachen university as an academic supporter of industrial innovations. However, the list of citations in the appendix simply document the firms' responses. Since the sample of firms in the innovation questionnaire is comparatively small, the citation list should in no manner be considered as a ranking of research institutions in Germany.

Only one institute of the Max-Planck-Society was mentioned by one company and indeed just one albeit the largest of the federal research-labs for big-science were cited at all: the German research laboratory for space and aviation (DLR). In relation to their size this is a rather disappointing result, even though, the questionnaire was only sent to a sample of firms. Together with what was said in chapter two the absence of citations of non-academic research other than Fraunhofer-Institutes suggests that further efforts to focus on industrial innovations and to intensify technology transfer to the industry are needed in order to fulfil the economic justification for their public funding.

11 See table A1 in the appendix for the list of universities and research lab that were cited by at least two firms. This result is not a ranking of single institutions and should not be taken as such. It is derived from a sample of all companies only and not from a census of firms that worked together with public research institutions. Moreover, as a result of the design of the question we cannot compare the importance of a single institution of one group with one of another group. It should only give a further hint of the distribution of academic sources within each group, that are most valuable for companies' innovation activities. The frequent reference of East German universities is biased by the overrepresentation of East German firms in the sample. 
On an international level the result is rather dull. Despite the EU-Commission's support of Pan-European collaboration between companies and public research institutions and cross-border networking, only three foreign institutions, of which one was European, were cited as being important for innovation by German firms. This suggests that proximity to public research, either physical or cultural, might be an essential determinant of technology transfer to private business. We will address the question whether spillover knowledge from public research is effected by regional distance together with firm specific determinants of effective technology transfer in the next chapter.

\section{Effects of Firm Size, R\&D and Distance to Public Research Institutions}

\subsection{R\&D Activity and Size of Firms}

There is rich empirical evidence that the usage of external knowledge by firms is no substitute for own generation of knowledge. Rather, external and internal knowledge act as complements. The opportunity to use knowledge from basic research presents a strong incentive for firms to do R\&D on their own in order to be able to adopt external knowledge in their own innovation production. The more firms are committed to their own R\&D activities the more they use external knowledge. The complementary relationship between internal and external knowledge holds especially for public and private R\&D (Leyden, Link, 1991a). Berman (1990) finds that firms even raised their R\&D-budgets after co-operating with universities. Cohen and Levinthal (1990) suggest that firms must build up an absorptive capacity with own R\&D activities to effectively incorporate external knowledge into new products and processes. In particular, public research seldom leads to ready-to-produce innovations. What actually gets transferred is knowledge that enables firms to develop a new product or process (Bloedon, Stokes, 1994, p. 44). Thus, we expect that firms with higher R\&D expenditures per sales have a higher propensity to receive knowledge spillovers from public research.

For years, economists have pursued the question of whether large firms tend to be more innovative than small firms. Fascinated by large R\&D labs many succumb to the view that large companies generate the innovations derived from basic research, while small firms rather imitate and thus disseminate innovations within industry. A closer examination led to the finding that small firms are sometimes much more innovative in relation to their size than large ones (Acs, Audretsch, 1990, Harhoff et al., 1996). The size of the firm includes many factors determining its behaviour. Size is rather a proxy for factors that correlate with size than the explaining variable itself. It is a proxy for scale effects of knowledge production, the capacity to specialise functions and to perform applied research as well. If innovation output cannot be measured in relation to size, the size variable also includes the higher innovation output of larger firms. As discussed above, the possibility to receive spillover knowledge from public research should increase with size because of increasing abilities to communicate and cooperate with public research institutions. From the perspective of the public scientists large firms could be more attractive to co-operate with, since large firms offer more complementing resources and funds, reputation and future job opportunities. 


\subsection{Regional Spillover}

Studies of industrial agglomerations and firm formation in high-tech industries stress the importance of proximity of private and public R\&D activities for spillover-effects. Case studies of Silicon Valley, Boston Route 128 (Saxenian, 1994) and the Cambridge science park (Castells, Hall, 1994) represent a starting point: They identify a regional innovation milieu which is characterized by intensive collaboration, informal contacts and technology transfer within the business sector (e.g. Camagni, 1991). The innovation milieu is seen to foster the commercialisation of new technologies and firm formation in high-tech-industries. These regional examples always have universities as a core which generate spillovers received predominantly by companies located in the same area. Technology transfer is seen to be most effective within informal communication networks. The main explanation for effects of proximity is that if research outputs cannot be reduced to formal sets of codified instructions it can not be transferred over long distances and requires face-to-face-communication (Foray, Mairesse, 1997). Even video-conferencing, widely used by multinational companies for global new product development, could hardly substitute personal communication (Nohria, Eccles, 1992, McDonough, Kahn, 1996). The incentive to work together with public research institutions should be higher for firms that are located closely to these public institutes, since the cost of travelling between collaborators increases with distance between them. A second argument is that there should be more occasions for informal communication between scientists of private firms and public institutions, who live in the same region. Moreover, collaboration between scientists often begins informally and result from casual conversation (Katz, 1994, p. 32). Informal communication leads to mutual trust, and trust raises the propensity to co-operate in R\&D-projects, since cooperations always increase the risk of know-how leaking out (Granovetter, 1985, Beise, Spielkamp, 1996). Therefore, more collaboration between nearby partners than between more distant ones should be observed. Local politics prefer the theses of research institutions being mostly beneficial for the regional industry and devoting their work to building up public research institutions in industrially underdeveloped regions.

On a broader statistical basis a positive regional interaction effect between academic and private R\&D-activities was supported for the US by the work of Jaffe (1989), Acs, Audretsch and Feldman (1992), Jaffe, Trajtenberg and Henderson (1993) and Anselin, Varga and Acs (1997) with patent, patent citation and single innovation counting as innovation indicators. ${ }^{12}$ Yet, there is ample criticism of the generalisation of the Silicon Valley story and the dominance of regional over interregional effects of public research (Bania, Eberts, Fogarty, 1993). First, direct measurements and the information on mechanism of the technology transfer from research institutions are scarce, and it is not clear what exactly caused the agglomeration effect. All measured effects could still be the effects of a regional market for skilled labor and spin-offs and not of technology transfer and intensive communication between local researchers. Spin-off firms are more frequent within research intensive regions, because of the immobility of scientist and engineers of research institutions that become entrepreneurs. Jaffe et al. (1993)

12 For an overview of studies on regional effects of universities see Anselin, Varga and Acs (1997). 
admit that it is still not known what spillover mechanisms are at work. Contrary to anecdotal evidence for informal collaboration and face-to-face-contacts in high-tech regions, Audretsch and Stephan (1996) find that even in the case of a science-based technology like biotechnology, 70 percent of 445 identified firm-university links are non-local. Secondly, other case studies of agglomerations did not find any form of innovation milieu, which is suggested to be the prerequisite of local technology transfer. In case studies of regional high-tech-regions in Europe companies just did not collaborate preferentially within their region (Castels, Hall, 1994). Thirdly, the influence of distance seems to depend highly on the innovation behaviour of the firm. MeyerKrahmer (1985) suggests that for R\&D-intensive and outward oriented innovating firms distance to the source of know-how is irrelevant and quality of external technology to be assessed is the only important factor.

There is also doubt about the applicability for Germany. Studies in the US normally use a regional entity, that is relatively large compared to Germany, which covers a smaller area than California. ${ }^{13}$ Germany has in addition built up a dense transportation infrastructure, making it sometimes more convenient to travel between two metropolitan areas than wangling one's way through the traffic jam within one city. Though regional policy and heavy public subsidies for science parks are common in Europe, „Silicon valley,, seems to be a US-specific phenomenon. Sternberg (1996) notes that there is no evidence yet for specialised industrial districts in Germany at all. Furthermore, few examples of dominant regional agglomerations around universities like the Silicon Valley are found in Germany. Although, there is some evidence for a positive relationship between universities and firm formation in high-tech industries (Licht, Nerlinger, 1998), the same does not hold for R\&D-co-operations. A survey of technology transfers from the Aachen university (Fromhold-Eisebith, 1992) found most of the companies which collaborated with the machinery faculty of the university to be located outside the region. Indeed, only 15 percent belonged to the Aachen region and one third were located in the southern German states of Bavaria and Baden-Wuerttemberg. An earlier study based on the Mannheim Innovation Panel by Beise and Spielkamp (1996) showed that, although, the share of co-operations with universities in the region exceeds that of regional customers or suppliers, only one quarter of the medium-sized companies and less than 10 percent of the companies with more than 500 employees, which co-operated with universities in 1992, did so solely within their region. In addition, company surveys by Sternberg (1997), Beise and Spielkamp (1996) and Grotz and Braun (1997) found support for the prevalence of interregional linkages between firms and public research institutions in Germany. It seems that within Germany distance did not matter much for high-tech firms. Apart from start-ups it might be argued that German R\&D performing companies lose their dependence on local research institutions.

13 Though Mansfield (1995) and Mansfield and Lee (1996) find support that firms are more reluctant to support research at a college or university 1,000 or more miles away than if it were less than 100 miles. The largest distance in Germany (from the north east to the south west) is only 600 miles. 


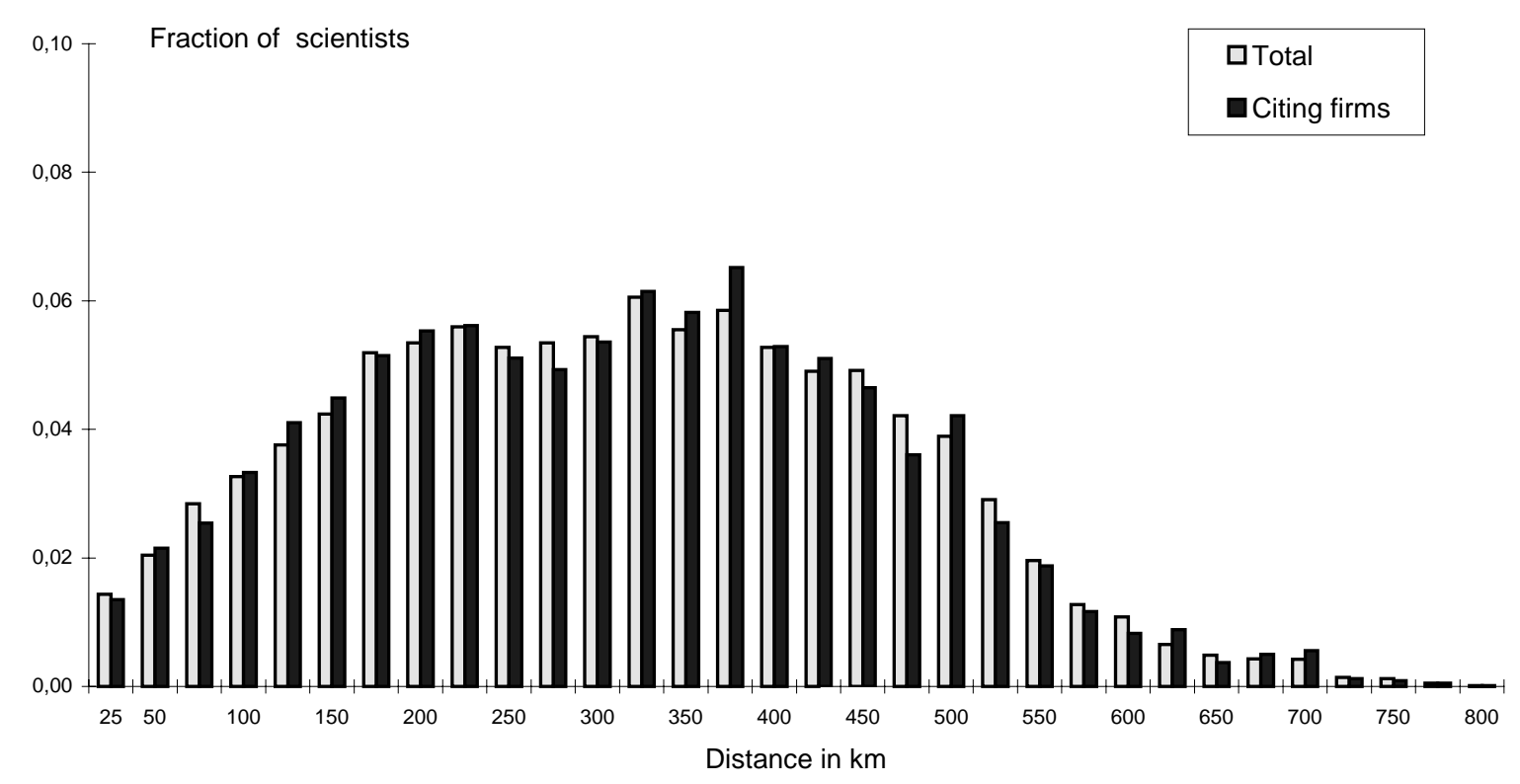

fig. 1 Histograms of distances of researchers at public research institutions (a) to all firms (b) to firms with public-research-based innovations

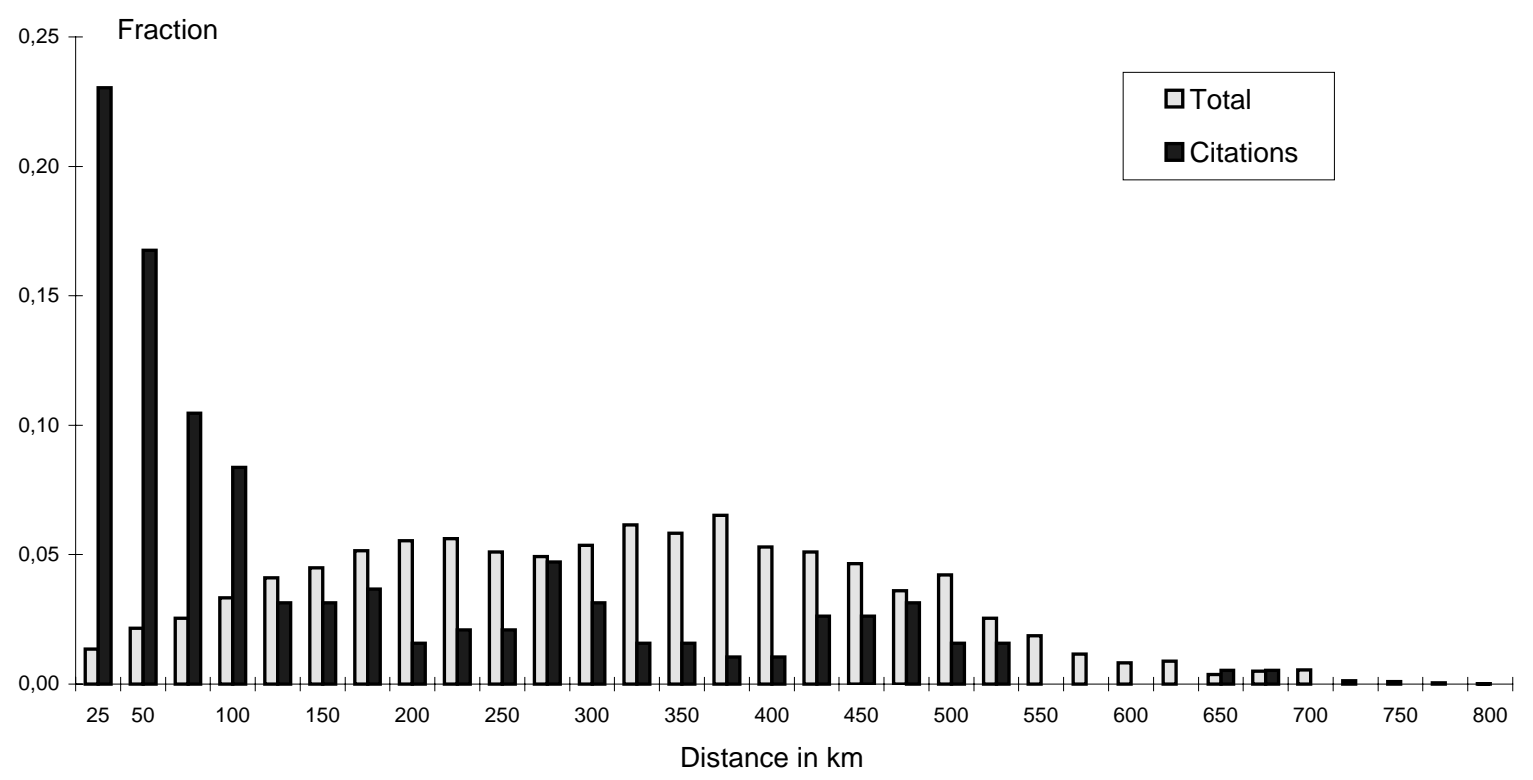

fig. 2 Histograms of distances of citing firms to (a) cited research institutions (b) to all researchers at public research institutions 

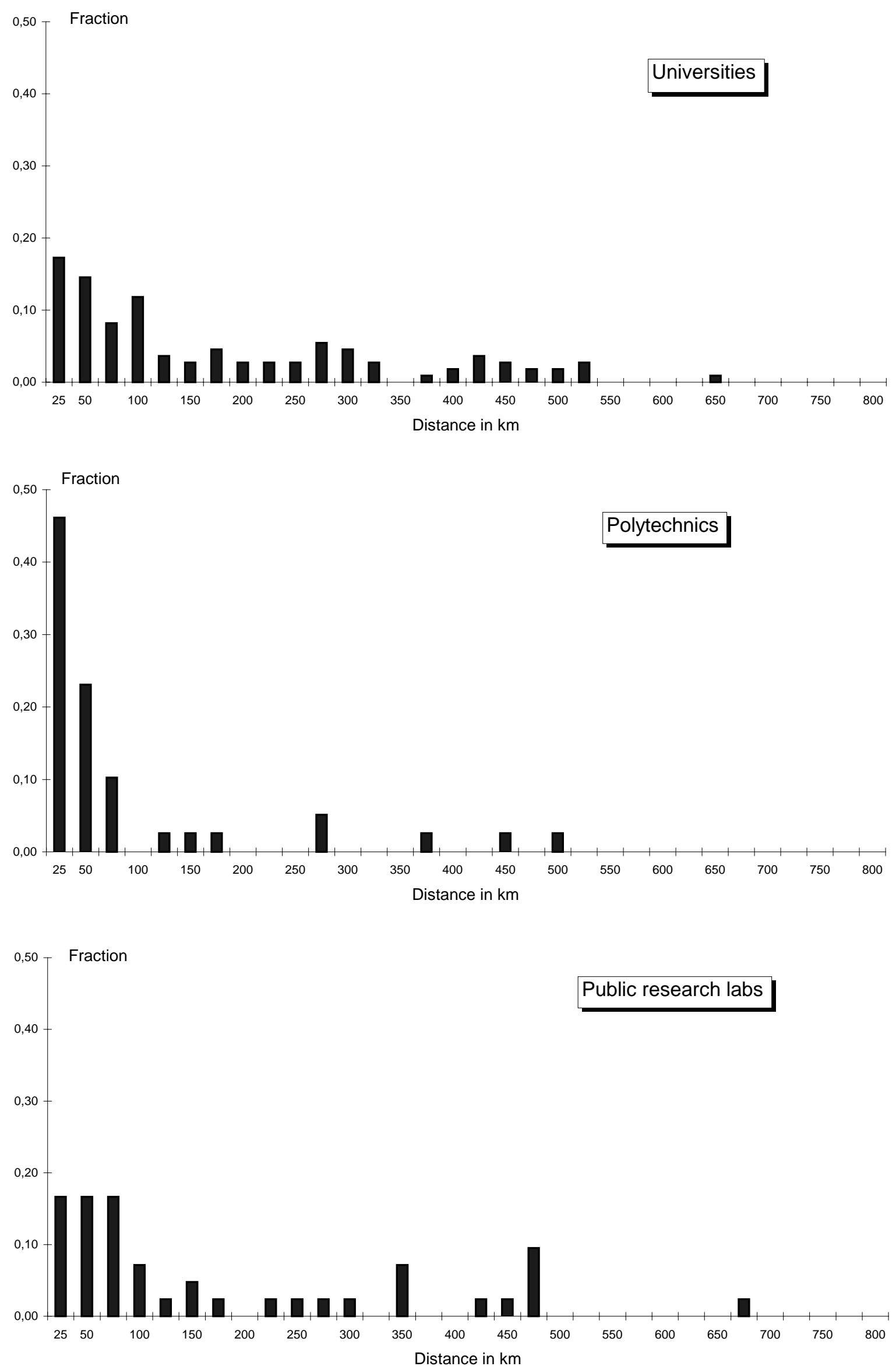

fig. 3 Histograms of distances between firms and cited research institutions 
If there is any regional bias of spillovers from public research, we would expect that firms with public-research-based innovations to be located closer to public research institutions on an average than other firms. Contrary to this expectation, a comparison of the distributions of distances of scientists employed by public research to companies of the sample shows no difference between firms with publicly supported innovations and all firms (fig. 1). With this finding, it is hard to believe that closeness to research institutions has an effect on the probability of public-research-based innovations. On the other hand, we find that firms naming specific research institutions do tend to be closer to these than to public institutions. The distribution of distances between citing firms and cited research institutions are highly skewed towards smaller distances compared to the distribution to all public scientists (fig 2). Almost one quarter of the 191 cited research institutions were located in the same county or in nearby counties not more than $25 \mathrm{~km}$ away. Looking at the different types of research institutions, it becomes clear that polytechnics, which have been founded mainly to support local small and medium sized firms, were named almost entirely by nearby firms as a useful knowledge resource (fig 3).

If we remove the polytechnics, the distribution of proximity to remaining research institutions turns out a lot more even. But also with universities and public research institutes like the ones of the Fraunhofer-Society, the majority of the cited institutes are located inside a $100 \mathrm{~km}$ circle (fig. 3). We conclude that firms tend to name institutions close by although, there is no higher probability to receive spillover knowledge from public research by firms that are located closer to these institutions compared with more remote firms. An explanation is that firms which decide to use external knowledge, start checking public research institutions nearby for reasons of convenience and look for more distant sources only if they fail to find any appropriate knowledge in their own region. The average distance of spillovers depends on the selection behaviour of the firm and not on the regional reach of spillovers from public research.

\subsection{Model Specification and Estimation}

Finally, we formulate the hypothesis that the amount of spillover knowledge received by a firm rises with the firm's R\&D-activities and the size of the firm. Our empirical model should also confirm that firms located close to public research institutions have no higher a probability of generating innovations with the support of public research by means of knowledge spillover or R\&D-co-operations. To test the hypothesis we use a simple model for the probability of industrial innovations with public research support. We assume that firms have a fixed number of products in their product portfolio and that each product has a known length of life-cycle, after which the product is renewed. Then the number of innovations IPUB ${ }_{i}$ introduced by firm $i$ in a 3-year period derived with findings of public research, depends on the number of innovations $I_{i}$ the firm is expected to generate, and the propensity g to receive spillover knowledge from public research. The spillover propensity should be dependent on the R\&D and size of the firm itself as well as closeness to public research institutions. This can be written as

$$
I P U B_{i}=I_{i} \cdot g\left(R \& D_{i}, \text { SIZE }_{i}, C_{L O S E N E S S}\right)
$$


We approximate the expected number of innovations with the number of product innovations the firm has to introduce to substitute existing products which are at the end of their product-life-cycle. For instance if a firm has three products, e.g. car models, and the product life cycle is 6 years, the firm has to introduce 1.5 new models on an average within a 3-year term. In general, the number of product innovations $n$ of a firm with $\mathrm{m}$ products in a 3 -year term can be formulated as

$$
I_{i}=3 \cdot \sum_{j=1}^{m} P L C_{j i}^{-1} .
$$

If the lengths of PLCs of all products are the same, we get

$$
I_{i}=\frac{3 \cdot m}{P L C_{i}}
$$

The probability of innovations is thus closely dependent on the length of the productlife-cycle (PLC) and the number of products of the firm's product range m. Since we do not know the number of innovations but only whether a firm had introduced publicresearch-based innovations or not, the dependent variable is a binary variable. Hence, we test the effects of firm and location specific variables on the probability of publicresearch-based innovations using a probit model. The PLC was estimated by the average over the lengths of the life-cycles of up to four main product lines given in the questionnaire. The number of products of the firm is indexed by the inverse of the Herfindal index for the sales distribution over four main product groups. It mainly serves as an indicator for the degree of diversification but equals the number of products if all products have the same sales share. ${ }^{14}$

As the variable representing the closeness to public research we take the share of scientists employed by public research institutions which are located in counties not more than $100 \mathrm{~km}$ away from the firm's county. ${ }^{15}$ Citations in the same county were arbitrarily assigned a distance of $10 \mathrm{~km}$. As mentioned before, the firm's own R\&D is expected to be a requisite for using external knowledge. Since R\&D expenditure of the years before the introduction of the innovations are not available for all firms in the sample, we use the current R\&D-intensity as a proxy. For the size variable we include the logarithm of the number of employees. We also add dummies for cutting-edge technologies (pharmaceuticals, agri-chemicals, telecommunication equipment, aircraft and electronic components) and capital-goods producing industries to control for industry specific factors such as technical opportunities and the supply effects due to the large size of public research in Germany in strategic high-technologies and engineering

14 The variable was calculated as the inverse of sums of squared sales shares of the 4 major product groups multiplied. A single product firm will have the value 1 (see Koenig, Licht, 1995).

15 The regional units used are the 543 German counties (Kreis), which correspond to the NUTS 3 level. Cities with universities are normally a metropolitan county (Kreisfreie Stadt). The distance between counties was calculated by using the linear distance of the counties' centres of a metric map projection. 
technologies. A dummy indicating an East German firm is included because these firms are expected to hinge more to East German research institutions due to the network of personal contacts within former East Germany. We apply the regression model first to all public-research-based innovations, and secondly to innovations, which were mainly supported by the three groups of public research institutions. The first regression estimates the probability of a firm's public-research-based innovations, whereas the other three regressions estimate the probability that a firm used findings of one group of public science institutions against firms with no public-research-based innovations or which used findings of the other two sources only. We include only firms as observations that have introduced product or process innovations in the 3-year period. Table 6 shows the regression results with marginal effects and standard errors.

The propensity to adopt spillovers from public research increases with the size of the firm as well as with the R\&D-intensity. This supports the view that the firm must first build up an absorption capacity to be able to adopt external knowledge. Spillovers from public research labs seem to require much more in-house $R \& D$, while polytechnics show no discrimination between $R \& D$ and non-R\&D intensive firms. Furthermore, polytechnics are equally supportive to small and to large firms. Contrary to expectations, the diversification variable has a significant but negative coefficient. It suggests that the more the company focuses on innovations, the more likely it is that they can incorporate findings of public research into their innovations. The length of the product-life-cycle has the expected sign but is significant only for polytechnics. As has been seen in figure 1, there is no general significant impact of closeness to public research institutions on the ability to receive valuable spillovers from them. Yet, the regressions reveal that firms are more likely to receive help from polytechnics if they are located far off from universities and other research institutions. While universities tend to be more oriented towards capital-goods innovations, polytechnics and public research centres seem to support high-tech innovations. Overall there is no bias towards these industries, when the R\&D intensity of firms is included.

Summarising, we find that German firms tend to cite research institutions close by more often than institutions further away. But firms which are closer to public research have no higher propensity to receive public research spillover. Yet, polytechnics are different from universities and public research centres. Polytechnics tend to support small companies more within their region, while universities and other research labs transfer knowledge more effectively towards larger companies with no regional priority. 
Table 6

Probit Estimations for companies with innovations, which could not have been developed without public research (marginal effects) ${ }^{\text {abcd }}$

\begin{tabular}{|c|c|c|c|c|}
\hline & All & Universities & Polytechnics & $\begin{array}{l}\text { Public research } \\
\text { labs }\end{array}$ \\
\hline $\ln ($ employment $)$ & $\begin{array}{l}0.024 * * * \\
(0.007)\end{array}$ & $\begin{array}{l}0.022 * * * \\
(0.004)\end{array}$ & $\begin{array}{l}0.0038 \\
(0.0027)\end{array}$ & $\begin{array}{l}0.014 * * * \\
(0.004)\end{array}$ \\
\hline R\&D-intensity & $\begin{array}{l}0.0042 * * * \\
(0.0022)\end{array}$ & $\begin{array}{l}0.0016 \\
(0.0015)\end{array}$ & $\begin{array}{l}-0.00003 \\
(0.0006)\end{array}$ & $\begin{array}{l}0.0026 * * \\
(0.0013)\end{array}$ \\
\hline Product-life-cycle & $\begin{array}{l}-0.0011 \\
(0.0013)\end{array}$ & $\begin{array}{l}-0.0006 \\
(0.0007)\end{array}$ & $\begin{array}{l}-0.0018^{* *} \\
(0.0008)\end{array}$ & $\begin{array}{l}-0.0010 \\
(0.00079)\end{array}$ \\
\hline Range of Products & $\begin{array}{l}-0.011 * * \\
(0.0045)\end{array}$ & $\begin{array}{l}-0.0058 * * \\
(0.0022)\end{array}$ & $\begin{array}{l}-0.0044^{* *} \\
(0.0018)\end{array}$ & $\begin{array}{l}-0.0032 \\
(0.0027)\end{array}$ \\
\hline Public Scientists $^{\mathrm{e}}$ & $\begin{array}{l}-0.207 \\
(0.237)\end{array}$ & & & \\
\hline Universities $^{\mathrm{e}}$ & & $\begin{array}{l}-0.387 \\
(0.364)\end{array}$ & $\begin{array}{l}-0.471 * * \\
(0.195)\end{array}$ & $\begin{array}{l}-0.482 \\
(0.370)\end{array}$ \\
\hline Polytechnics $^{\mathrm{e}}$ & & $\begin{array}{l}0.197 \\
(0.403)\end{array}$ & $\begin{array}{l}0.586 * * * \\
(0.209)\end{array}$ & $\begin{array}{l}0.377 \\
(0.411)\end{array}$ \\
\hline $\begin{array}{l}\text { Public research } \\
\operatorname{labs}^{\mathrm{e}}\end{array}$ & & $\begin{array}{l}0.017 \\
(0.142)\end{array}$ & $\begin{array}{l}-0.127 * \\
(0.079)\end{array}$ & $\begin{array}{l}0.038 \\
(0.152)\end{array}$ \\
\hline Capital goods sectors & $\begin{array}{l}0.038 \\
(0.024)\end{array}$ & $\begin{array}{l}0.039 * * \\
(0.016)\end{array}$ & $\begin{array}{l}0.016^{* *} \\
(0.0089)\end{array}$ & $\begin{array}{l}-0.0053 \\
(0.015)\end{array}$ \\
\hline $\begin{array}{l}\text { Cutting-edge tech- } \\
\text { nologies }\end{array}$ & $\begin{array}{l}0.007 \\
(0.051)\end{array}$ & $\begin{array}{l}0.011 \\
(0.035)\end{array}$ & $\begin{array}{l}0.058 * * \\
(0.040)\end{array}$ & $\begin{array}{l}0.066^{*} \\
(0.048)\end{array}$ \\
\hline East German firm & $\begin{array}{l}-0.028 \\
(0.032)\end{array}$ & $\begin{array}{l}0.0034 \\
(0.019)\end{array}$ & $\begin{array}{l}0.0012 \\
(0.012)\end{array}$ & $\begin{array}{l}0.032 \\
(0.025)\end{array}$ \\
\hline No. Observations & 892 & 891 & 889 & 890 \\
\hline Log-likelihood & -371.4 & -213.4 & -136.9 & -206.4 \\
\hline Pseudo- $R^{2}$ & 0.0377 & 0.0931 & 0.1276 & 0.0605 \\
\hline$\chi^{2}$ - test (df) & $26.14(8) * * *$ & $50.38(10)^{* * *}$ & $46.42(10) * * *$ & $32.35(10)^{* * *}$ \\
\hline \multicolumn{5}{|c|}{$\begin{array}{l}\text { b Marginal effects calculated at the means of variables. See Table A2 in the appendix for the means of variables. } \\
\text { For dummy variables the partial effect is calculated as the discrete change of a dummy variable from } 0 \text { to } 1 .\end{array}$} \\
\hline \multicolumn{5}{|c|}{${ }^{c}$ Statistical significance at the $0.01 / 0.05 / 0.1$ level is denoted by $* * * / * * / *$} \\
\hline \multicolumn{5}{|c|}{${ }^{\mathrm{d}}$ Heteroskedasticity-robust standard errors in brackets } \\
\hline
\end{tabular}


The above findings suggest that knowledge spillovers from polytechnics have a much closer regional reach than spillovers from universities and public labs. The reach could also depend on the size of the research institution. It is expected that the larger the public institution the greater the reach of knowledge spillovers will be, because of the larger range of topics or because of the uniqueness of their work in fields with indivisibility. ${ }^{16}$ Since faculties of polytechnics are in general very small in contrast to those of universities and big science centres and rarely carry a unique research program of their own, their findings would seldom be of nation-wide interest. To discuss other determinants of the reach of knowledge spillovers from public research, we examine the influence of firm specific factors on the distance between citing firm and cited research institution. First, one would expect larger firms to be more able or capable in communicating and co-operating with more remote partners than small companies. Agglomeration literature suggests small high-tech firms prefer close contacts to nearby firms for exchanging knowledge. On the other hand firms with a larger R\&D staff should be more capable of receiving technological knowledge from more remote research sources.

Let us now examine firm-specific factors which led to the use of knowledge from remote public research, that is to name a more distant institution as its most valuable source of knowledge. In the second model we regress distance between the firm and the cited public research institution on size and R\&D-intensity. To take the geographical distribution of public research institutions and their varying proximity to firms into account, we use the relation of the actual distance to the average distance to all public scientists in Germany as the endogenous variable. A dummy for firms from East Germany was included to control for East German effects mentioned above. Some industries agglomerate in particular regions in Germany like the textile industry in the southwest of Germany or the steel industry in the Ruhr area. Often industrial districts were subsequently supported by complementary public research in the same region. Since we cannot differentiate public research according to technology, we include dummies for 16 manufacturing industries to control for general industry agglomeration effects. We also control for the three types of public institutions with dummies. 164 of the 174 pairs of citing firms and cited public institutions the number of scientific staff of the public institution were identified. For the fraction of the sample we include the size of the cited research institution. We formulate our model as

$$
\frac{\operatorname{dist}_{j p}}{\overline{\operatorname{dist}}_{j}}=f\left(S I Z E_{j}, R \& D_{j}, E A S T_{j}, I N S_{p}, a_{p}\right)
$$

with

$$
\overline{\operatorname{dist}}_{j}=\frac{\sum_{p} \operatorname{dist}_{j p} a_{p}}{\sum_{p} a_{p}}
$$

16 For very few research institutions, size is dependent on the success of technology transfers to private businesses. 
with the distance dist $t_{\mathrm{jp}}$ between citing firm $\mathrm{j}$ and cited public research institution $\mathrm{p}$, the average distance dist $t_{j}$ of firm $j$ to public scientists, the size of the citing firm $j$ and the cited research lab $\mathrm{p}$ and $\mathrm{a}_{p}$ the number of its researchers. Table 7 shows the OLS regression results. Again, it is the R\&D-intensity which determines the radius of access to knowledge from public research by companies and not firm size. The more the firm spends on $\mathrm{R} \& \mathrm{D}$ divided by sales the more it looks beyond its region to get the best possible scientific knowledge. This clearly supports the anecdotal evidence for Germany that R\&D-intensive companies are not bound to their region - albeit companies in East Germany seem to be more focused on public research within their region or within East Germany than firms in West Germany. As fig 3 suggests, there is a highly significant difference between polytechnics and the other institutions, with the former used mainly by local companies. The size of the research institution has no effect on the distance when the type of institutions is included in the regression. Only two sectors show significant differences. Producers of textile are clustered in regions in the south-west of Germany, so are the public research institutions specialised in textile research. Producers of glass, stone and clay are on an average more distant to their most important public research institutions.

Table 7

OLS-regressions of the distance to cited research institution in relation to the average distance of firm to all research institution

\begin{tabular}{lll}
\hline Variables & $\mathrm{A}$ & $\mathrm{B}$ \\
\hline $\ln ($ employment $)$ & 0.011 & 0.017 \\
& $(0.020)$ & $(0.021)$ \\
R\&D-expenditure per sale & $0.017 * *$ & $0.017 * *$ \\
& $(0.0087)$ & $(0.0087)$ \\
University & 0.021 & -0.120 \\
& $(0.097)$ & $(0.138)$ \\
Polytechnics & $-0.302^{* * * *}$ & $-0.375^{* * *}$ \\
& $(0.107)$ & $(0.125)$ \\
ln(Employment of research lab) & & 0.020 \\
& & $(0.056)$ \\
East German Firm & $-0.181 * *$ & $-0.143 *$ \\
& $(0.075)$ & $(0.087)$ \\
Textile, apparel, leather & $-0.307 * * *$ & -0.204 \\
& $(0.099)$ & $(0.132)$ \\
Glass, Mineral Products & $0.602^{* * *}$ & $0.901 * * *$ \\
& $(0.235)$ & $(0.160)$ \\
\hline No. Observations & 174 & 162 \\
Pseudo- R ${ }^{2}$ & 0.146 & 0.1585 \\
F-Test (df) & $6,02(7) * * *$ & $8.26(8) * * *$ \\
\hline a Calculated with Stata 5.0. & & \\
${ }^{\mathrm{b}}$ Heteroskedasticity-robust standard & errors in brackets. & \\
${ }^{\mathrm{c}}$ Statistical significance at the $0.01 / 0.05 / 0.1$ level is denoted by $* * * * * * *$ & \\
& &
\end{tabular}




\section{Conclusions}

This paper presents results of a recent survey on industrial innovations that have been made possible by academic and other publicly funded research. Using an extensive survey of companies in the manufacturing sector, it attempts to quantify the effects of public research on industrial innovations which is the economic justification for public research. In a second step we examine effects of firm-specific factors on the propensity of firms to use and incorporate knowledge generated by public research for these innovations. Summarising the findings, we conclude that public research has indeed an immediate effect on industrial innovations. One of the basic findings is that a considerable share of companies have identified product and process innovations, which they would not have developed in the absence of recent research of public institutions and that some of them are in the position of naming the specific source of the research output they used. The results are similar to the findings of Mansfield (1991) for the US. This shows that overall public research may transfer technology successfully to industrial companies.

Yet, the results must be considered with some caution. We only include publicresearch-based innovations identified by the firms directly, and not innovations that have not been perceived as requiring essential public support despite their science base. Furthermore, it is likely that we get only the short-term effects of public research. But even if we take the limitations into account, we would conclude that there is not much evidence of publicly funded research in Germany being fully justified by identifiable transfers to industrial innovations. Probably more convincing is the evidence for differences in the effectiveness of technology transfer between various types of public research institutions. It seems that the success of technology transfer is connected with the share of research grants from industry. The most effective public research institutions are financed to a considerable amount through project-related and industry research funds. Taking away the Fraunhofer-Society institutes for applied research and the respected large technical universities like Aachen with excellent research oriented towards industrial innovation, there is not much appreciation for public research by private businesses with respect to industrial product and process innovations. Especially the federal research centres, which are to support industrial innovations, should reconsider their research strategy. That also means the distinction between effective and ineffective public research cannot be made by institutions of applied and basic research. Public research centres are supposed to perform much more applied research than universities. Yet, it is only the universities which are named frequently. Personal commitment of academic scientists and the higher fluctuation in academic research could be responsible for the greater impact of universities and Fraunhofer-institutes, for they have the highest employment turnover within the research infrastructure. Technology transfer occurs through qualified academics in firms' R\&D labs using the knowledge they received at public research institutions. This is where big science labs and other non-academic public research fail. They do not spin off much human capital, for one of their justification is that they care for long-term research requiring low staff turnover rates. 
For a technology policy these conclusions are highly relevant. First, although Germany provides a variety of public research institutions, the effectiveness of technology transfer varies considerably between institutions. Promoting technology transfer can be accomplished by shifting funds from ineffective to more effective research institutions, as well as by changing the way the ineffective institutions, conduct their role of transferring technology to industry. Secondly, proximity may not be of equal importance within Germany than within other countries, especially in the US. The hypothesis that proximity is important especially for high-tech or R\&D-intensive industries is clearly rejected in the case of Germany. Lastly, if technology transfer is mainly effective in the formation and transfer of human capital, i.e. qualified academics, then public research consequently has to support this transfer channel. Thus education and short-term research of scientists and engineers in public research labs should become an essential feature of the national technology policy. 


\section{References}

Abramson, H.N., J. Encarnação, P.P. Reid, U. Schmoch, 1997, Technology Transfer Systems in the United States and Germany: Lessons and Perspectives, National Academy, Washington, D.C.

Acs, Z., D. Audretsch, 1990, Innovation and small firms, MIT, Cambridge, Mass.

Acs, Z., D. Audretsch, M. Feldman, 1992, Real Effects of Academic Research: Comment, American Economic Review 82, 363-367.

Adams, J. D., 1990, Fundamental Stocks of Knowledge and Productivity Growth, Journal of Political Economy 98, 673-702.

Anselin, L., A. Varga, Z. Acs, 1997, Local Geographic Spillovers between University Research and High Technology Innovations, Journal of Urban Economics 42, 422-448.

Arrow, K.J., 1962, Economic Welfare and the Allocation of Resources for Invention, in: R. Nelson (ed.), The Rate and Direction of Inventive Activity: Economic and Social Factors, Princeton Univ., Princeton, 609-625.

Audretsch, D., P. Stephan, 1996, Company-Scientist Locational Links: The Case of Biotechnology, American Economic Review 86, 641-652.

Bania, N., R. Eberts, M. S. Fogarty 1993, Universities and startup of new companies: can we generalize from Route 128 and Silicon Valley? The Review of Economics and Statistics 75, 761-766.

Beise, M., A. Spielkamp, 1996, Technologietransfer von Hochschulen: Ein InsiderOutsider-Effekt, ZEW-Discussion Paper No. 96-10, Mannheim.

Berman, E. M., 1990, The economic impact of industry-funded university R\&D, Research Policy 19, 97-114.

Bloedon, R. V., D. R. Stokes, 1994, Making University/Industry Collaboration Research Succeed, Research Technology Management 24, 373-386.

BMBF (German Ministry for Education, Science, Research and Technology), 1996, Bundesbericht Forschung 1996, Bonn

BMBF (German Ministry for Education, Science, Research and Technology), 1998, Germany's Technological Performance: Updated and Expanded Report, Bonn.

Brooks, H., 1994, The relationship between science and technology, Research Policy 23, 477-486.

Brooks, H., 1996, The Evolution of U.S. Science Policy, in: B.L.R. Smith, C.E. Barfield (eds.), Technology, R\&D, and the Economy, Brookings Institution, Washington, 15-40.

Cahan, D., 1989, An institute for an empire: the Physikalisch-Technische Reichsanstalt, 1871 - 1918, Cambridge Univ., Cambridge.

Camagni, R. (ed), 1991, Innovation networks: spatial perspectives, Belhaven, London. 
Castells, M., P. Hall, 1994, Technopols of the World - The making of twenty-firstcentury industrial complexes, Routledge, London.

Cohen, W., 1995, Empirical Studies of Innovative Activity, in: Stoneman, P. (ed.), Handbook of Economics of Innovation and Technical Change, Blackwell, Oxford, 182-264.

Cohen, W., R. Florida, W. R. Goe, 1994, University-Industry Research Centers in the United States, Research Report Carnegie Mellon University, Pittsburgh.

Cohen, W., D. Levinthal, 1990, Absorptive Capacity: A New Perspective on Learning and Innovation, Administration Science Quarterly 35, 128-152.

Dasgupta, P., P.A. David, 1994, Towards a New Economics of Science, Research Policy 23, 5, 487-521.

Foray, D., J. Mairesse, 1997, Sur le financement public de la recherche de base: la voix de l'économie de la recherche, mimeo.

Fromhold-Eisebith, M., 1992, Meßbarkeit und Messung des regionalen Wissens- und Technologietransfers aus Hochschulen, in: NIW (ed.), Erfolgskontrollen in der Technologiepolitik, NIW-Workshop 1992, Hannover, 117-136.

Gemuenden, H. G. und Walter, A. (1997): The Relationship Promoter - Initiator, Motivator and Co-Ordinator for Inter-Organisations Innovation Co-Operation, in: $\mathrm{H}$. G. Gemuenden, T. Ritter, A. Walter (eds.), Relationships and Networks in International Markets, Oxford, Elsevier, 180-197.

Gibons, M., R. Johnston, 1974, The Role of Science in Technological Innovation, $R e$ search Policy 3, 220-242.

Granovetter, M., 1985, Economic Action and Social Structure: The Problem of Embeddedness, American Journal of Sociology 91, 3, 481-510.

Grotz, R., B. Braun, 1997, Territorial or Trans-territorial Networking: Spatial Aspects of Technology-oriented Cooperation within the German Mechanical Engineering Industry, Regional Studies 31, 545-557.

Harhoff, D., 1998, Are there Financing Constraints for R\&D and Investment in German Manufacturing Firms? Annales d'Économie et de Statistique (49-50), 421456.

Harhoff, D. et al., 1996, Innovationsaktivitaeten kleiner und mittlerer Unternehmen: Ergebnisse des Mannheimer Innovationspanels, Schriftenreihe des ZEW, No. 8, Nomos, Baden-Baden.

Hauff, V., F. W. Scharf, 1975, Modernisierung der Volkswirtschaft: Technologiepolitik als Strukturpolitik, Europaeische Verlagsanstalt, Frankfurt.

Hetmeier, H.-W., 1998, Methodik der Berechnung der Ausgaben und des Personals der Hochschulen fuer Forschung und experimentelle Entwicklung ab dem Berichtsjahr 1995, Wirtschaft und Statistik (2), 153-163. 
Hohn, H.-W., 1989, Forschungspolitik als Ordnungspolitik: Das Modell FraunhoferGesellschaft und seine Genese im Forschungssystem der Bundesrepublik Deutschland, MPIG Discussion Paper 89/8, Koeln.

Jaffe, A., 1989, Real Effects of Academic Research, American Economic Review 79, 957-970.

Jaffe, A., M. Trajtenberg, R. Henderson, 1993, Geographic Localization of Knowledge Spillovers as Evidenced by Patent Citations, Quarterly Journal of Economics 108, 577-598.

Jensen, R., M. Thursby, 1998, Proofs and Prototypes for Sale: The Tale of University Licensing, NBER Working Paper No. 6698, Washington, D.C.

Johnson, J. A., 1990, The Kaiser's chemists: science and modernization in imperial Germany, Univ. of North Carolina, Chapel Hill, NC.

Jones, Ch. I., J.C. Williams, 1997, Measuring the Social Return to R\&D, Stanford University Working paper, forthcoming in Quarterly Journal of Economics.

Katz, J. S., 1994, Geographical Proximity and Scientific Collaboration, Scientometrics 31 (1), 31-43.

Kealey, T., 1998, Why science is endogenous: a debate with Paul David (and Ben Martin, Paul Romer, Chris Freeman, Luc Soete and Keith Pavitt), Research Policy 26 (7-8), 897-923.

Keck, O., 1976, West German science policy science the early 1960's: trends and objectives, Research Policy 5, 116-157.

Keck, O., 1980, Government policy and technical choice in the German reactor program, Research Policy 9, 302-356.

Keck, O., 1993, The National System for Technical Innovations in Germany, in: R. Nelson (ed), National innovation Systems, Oxford Univ., Oxford, 115-157.

Kline, S. J., N. Rosenberg, 1986, An Overview of Innovation, in: R. Landau, N. Rosenberg (eds.), The Positive Sum Strategy, National Academy, Washington, 275305.

Koenig, H., G. Licht, 1995, Patents, R\&D and Innovation, ifo Studien 41, 521-543.

Leyden, D. P., A. N. Link, 1991a, Why are Governmental R\&D and Private R\&D Complements? Applied Economics 23, 1673-81.

Leyden, D. P., A. N. Link, 1991b, Government's Role in Innovation, Kluwer, Dordrecht et al.

Licht, G., E. Nerlinger, 1998, New technology-based firms in Germany: a survey of recent evidence, Research Policy 26 (9), 1005-1022.

Lundvall, B.-A., 1988, Innovation as an interactive process: from user-producer interaction to the national system of innovation, in: G. Dosi et al. (eds.), Technical Change and Economic Theory, Pinter, London, New York, 349-369. 
Mansfield, E., 1991, Academic research and industrial innovation, Research Policy 20, $1-12$.

Mansfield, E., 1995, Academic Research Underlying Industrial Innovations: Sources, Characteristics, and Financing, Review of Economics and Statistics 77, 55-65.

Mansfield, E., J.-Y. Lee, 1996, The modern university: contributor to industrial innovation and recipient of industrial R\&D support, Research Policy 25, 1047-1058.

Martin, B., A. Salter, 1996, The Relationship between Publicly Funded Basic Research and Economic Performance, A Spru Review, Report prepared for HM Treasury, University of Sussex, Brighton.

Mayntz, R., 1991, Scientific research and political intervention: The structural development of publicly financed research in the Federal Republic of Germany, in: A. Orsi Battaglini, F. Roversi Monanco (eds.), The University within the research System - An international comparison, Nomos, Baden-Baden, 45-60.

McDonough, E., K. B. Kahn, 1996, Using 'hard' and 'soft' technologies for global new product development, $R \& D$ Management 26 (3), 241-253.

Meyer-Krahmer, F., 1985, Innovation Behavior and Regional Indigenous Potential, Regional Studies 19, 6, 523-534.

Nadiri, M. I., 1993, Innovations and Technological Spillovers, NBER Working Paper No. 4423, Cambridge, Mass.

Narin, F., K. S. Hamilton, D. Olivastro, 1997, The increasing linkages between U.S. technology and public science, Research Policy 26, 317-330.

Nelson, R., 1986, Institutions Supporting Technical Advance in Industry, American Economic Review 76, 186-189.

Nohria, N., R. G. Eccles, 1992, Face-to-Face: Making Network Organization Work, in: N. Nohria, R.G. Eccles (eds.), Networks and organizations: structure, form, and action, Harvard Univ., Boston, MA., 288-308.

OECD, 1996, Proposed Guidelines for Collecting and Interpreting Technological Innovation Data: Oslo-Manual, 1. Rev., Paris.

OECD, 1997, Main Science and Technology Indicators, Paris.

Ritter, G.A., 1992, Großforschung und Staat in Deutschland: Ein historischer Ueberblick, C.H. Beck, Muenchen.

Rosenberg, N., R. Nelson, 1994, American Universities and Technical Advance in Industry, Research Policy 23, 323-348.

Saxenian, A., 1994, Regional Advantage: Culture and Competition in Silicon Valley and Route 128, Harvard Univ., Cambridge, Mass., London.

Schimank, U., 1990, Technology Policy and Technology Transfer from State financed Research Institutions to the Economy: some German Experiences, Science and Public Policy 17 (4), 219-228. 
Shapley, D., R. Roy, 1985, Lost at the Frontier: U.S. Science and Technology Policy Adrift, ISI, Philadelphia.

Stephan, P., 1996, The Economics of Science, Journal of Economic Literature 34, 1199-1235.

Sternberg, R., 1997, Intraregional versus Interregional Linkages between R\&D Institutions and Innovative SMEs - Empirical Results from Recent Surveys in German Regions. Paper presented to the European Network on „Networks, Collective Learning and RTD in Regionally-Clustered High-Technology SMEs,,, Munich, February $28^{\text {th }}$-March $1^{\text {st }}$.

Sternberg, R., 1996, Regionale Spezialisierung und raeumliche Konzentration FuEintensiver Wirtschaftszweige in den Kreisen Westdeutschlands - Indizien fuer Industriedistrikte? Berichte zur deutschen Landeskunde 70, 133-155.

Stokes, D. E., 1997, Pasteur's quadrant: basic science and technological innovation, Brookings Institution, Washington, D.C.

Szoelloesi-Janze, M., H. Trischler (eds.), 1990, Großforschung in Deutschland: Beitraege zur Geschichte eines Forschungstyps, Campus, Frankfurt, New York.

Tritschler, H., 1990, Planungseuphorie und Forschungssteuerung in den 1960er Jahren in der Luft- und Raumfahrtforschung, in: M. Szoelloesi-Janze, H. Trischler, 117139.

Wiegand, J., 1990, Die Gruendung der GMD - Mathematik oder Datenverarbeitung?, in: M. Szoelloesi-Janze, H. Trischler, 78-96.

Wissenschaftsrat, 1993, Drittmittel der Hochschulen 1970 bis 1990, Koeln. 


\section{Data Appendix}

Data were taken from the fourth wave of the Mannheim Innovation Panel. This multiyear innovation survey has been conducted by the Zentrum fuer Europaeische Wirtschaftsforschung (ZEW) and the Institut fuer angewandte Sozialforschung (infas). The Mannheim Innovation Panel (MIP) is part of the Community Innovation Survey (CIS) a joint effort of Eurostat and the EU Commission to collect firm level data on input and output on innovation throughout the European Union. The questionnaire follows the guidelines for innovation statistics containing in the OSLO-manual of the OECD (1996). In Germany, the survey is organised as an annual panel study which started in 1992. The sampling frame stems from the records of the largest credit rating company (Creditreform) in Germany. The sample is a stratified random sample and covers all manufacturing industries and selected service industries, e.g. software development, in West and East Germany. In our analysis the sample was confined to manufacturing industries. Enterprises with less than five employees are deliberately excluded. Industries which are supposed to be very innovative are oversampled. The survey is a postal survey with several reminders. Approximately 2,300 companies completed the questionnaire in the fourth year of the survey. The response rate was about 20 percent. To account for a possible bias arising from self-selection of innovative firms into the survey, a non-response analysis is conducted each year by phone, which yields a response rate of nearly 90 percent. Firms' weights are corrected for a positive response bias of innovating firms (see also Koenig, Licht 1995, p. 524).

Before the mailing of the first wave began, every enterprise with at least 250 employees, that is roughly a third of the sample, had been called by phone to check the address and to identify the person most suited to answer the questionnaire. Since we ask for the respondent's name and his function in the questionnaire we know that in firms with less than 100 employees normally a director answers and in larger firms the head of the $\mathrm{R} \& \mathrm{D}$ department. If there is none, it will again be the director who answers or his deputy. Of course, some information we ask for is not regularly gathered by the firms and so is difficult to provide, even for the person most suited. After the third wave we investigated in some regressions of key variables whether a change of the contact would have a statistically significant influence on the mean or variance of the estimated coefficients but until now we could not find any. So we believe that the - sometimes rather rough - figures provided by the firms are either only slightly biased or not biased at all. Errors should cancel out if the sample is sufficiently large and weights for raising are similar. Unfortunately, the weights are quite unequal and for some topics sample size is rather modest. We tried to mitigate that problem by carefully inspecting the data. For example, if an enterprise appears as influential in one investigation in one year we will pay special attention to it in all investigations in every year. So our estimates are rough but we believe they are still worth reporting. 
Table A1

Public research institutions cited by at least two companies as most important to the development of their innovations between 1993 and 1996

\begin{tabular}{|c|c|c|}
\hline Institution & $\begin{array}{l}\text { Percentage of } \\
\text { citations }\end{array}$ & $\begin{array}{l}\text { Percentage of } \\
\text { R\&D staff }{ }^{a}\end{array}$ \\
\hline Institutes of the Fraunhofer-Society (FhG) & 12.8 & 3.2 \\
\hline RWTH Aachen & 8.2 & 5.8 \\
\hline TU Dresden & 5.1 & 2.6 \\
\hline Universitaet Stuttgart & 3.1 & 2.1 \\
\hline Bergakademie Freiberg & 2.6 & 0.5 \\
\hline Universitaet Nuernberg-Erlangen & 2.6 & 2.8 \\
\hline Ruhruniversitaet Bochum & 2.6 & 2.6 \\
\hline TH Darmstadt & 2.6 & 1.5 \\
\hline Fachhochschule Nuernberg & 2.0 & 0.4 \\
\hline Universitaet Hannover & 1.5 & 1.2 \\
\hline TU Clausthal-Zellerfeld & 1.5 & 0.5 \\
\hline TU Hamburg-Harburg & 1.5 & 0.4 \\
\hline Fachhochschule Aachen & 1.0 & 0.7 \\
\hline TU Muenchen & 1.5 & 2.9 \\
\hline TU Berlin & 1.0 & 3.4 \\
\hline Universitaet Rostock & 1.0 & 1.3 \\
\hline Fachhochschule Aalen & 1.0 & 0.1 \\
\hline Uni Paderborn & 1.0 & 1.5 \\
\hline Uni Karlsruhe (TH) & 1.0 & 2.0 \\
\hline Uni Braunschweig & 1.0 & 1.4 \\
\hline $\begin{array}{l}\text { Deutsche Forschungsanstalt f. Luft- und } \\
\text { Raumfahrt (DLR), Koeln }\end{array}$ & 1.0 & 1.6 \\
\hline
\end{tabular}

\footnotetext{
${ }^{a}$ Share of scientific personnel in science, engineering and medical faculties in Germany (1993)
}

Source: ZEW Mannheim Innovation Panel, BMBF (1996), Statistisches Bundesamt (unpublished). 
Table A2

Descriptive statistics for the probit regressions

\begin{tabular}{|c|c|c|c|c|}
\hline Variable & Mean & Stand. Dev. & Min & Max \\
\hline \multicolumn{5}{|c|}{ Endogenous variables } \\
\hline $\begin{array}{l}\text { Public-research- } \\
\text { based innovations }\end{array}$ & 0.156 & - & 0 & 1 \\
\hline University & 0.074 & - & 0 & 1 \\
\hline Polytechnics & 0.043 & - & 0 & 1 \\
\hline $\begin{array}{l}\text { Public research } \\
\text { labs }\end{array}$ & 0.067 & - & 0 & 1 \\
\hline \multicolumn{5}{|l|}{$\begin{array}{l}\text { Exogenous vari- } \\
\text { ables }\end{array}$} \\
\hline $\ln ($ employment $)$ & 5.07 & 1.61 & 1.09 & 12.22 \\
\hline R\&D-intensity & 3.21 & 5.10 & 0 & 46.25 \\
\hline Product-life-cycle & 10.66 & 11.68 & 0 & 100 \\
\hline Range of Products & 3.83 & 10.46 & 1 & 222 \\
\hline East-German firm & 0.25 & - & 0 & 1 \\
\hline Public Scientists & 0.096 & 0.054 & 0.0009 & 0.227 \\
\hline Universities & 0.095 & 0.053 & 0 & 0.23 \\
\hline Polytechnics & 0.096 & 0.051 & 0 & 0.21 \\
\hline $\begin{array}{l}\text { Public research } \\
\quad \text { labs }\end{array}$ & 0.098 & 0.076 & 0.0002 & 0.23 \\
\hline $\begin{array}{l}\text { Capital goods } \\
\text { sectors }\end{array}$ & 0.55 & - & 0 & 1 \\
\hline $\begin{array}{l}\text { Cutting edge tech- } \\
\text { nologies }\end{array}$ & 0.54 & - & 0 & 1 \\
\hline
\end{tabular}

Source: ZEW Mannheim Innovation Panel 
Table A3

Descriptive statistics for the distance OLS regressions

\begin{tabular}{|c|c|c|c|c|}
\hline Variable & Mean & Std. Dev. & Min & Max \\
\hline \multicolumn{5}{|l|}{ Endogenous Variable } \\
\hline $\begin{array}{l}\text { Distance to cited insti- } \\
\text { tute divided by average } \\
\text { distance to all institutes }\end{array}$ & 0.481 & 0.489 & 0.023 & 1.793 \\
\hline \multicolumn{5}{|l|}{ Exogenous variable } \\
\hline $\ln ($ employment $)$ & 5.729 & 1.710 & 1.945 & 9.798 \\
\hline R\&D-intensity & 3.700 & 4.718 & 0 & 40 \\
\hline Universities & 0.586 & - & 0 & 1 \\
\hline Polytechnics & 0.189 & - & 0 & 1 \\
\hline Public research labs & 0.224 & - & 0 & 1 \\
\hline East German firm & 0.275 & - & 0 & 1 \\
\hline Textile, apparel, leather & 0.023 & - & 0 & 1 \\
\hline Glass, mineral products & 0.023 & - & 0 & 1 \\
\hline $\begin{array}{l}\text { Employment of cited } \\
\text { research institute }\end{array}$ & 1965.7 & 2184.9 & 10 & 7102 \\
\hline
\end{tabular}

Source: ZEW Mannheim Innovation Panel 